\title{
Zen Buddhism and the Encounter of World Religions
}

\author{
Eshin Nishimura
}

When we define a word "religion" as what is conbined, from its Ltian etymon religia, Zen Buddhism can not be in its category. Bacause the aim of Zen practice is not to seek, to unite with or to become the absolute Being, but to awake, to realize or to be inborn real Self. There is no distance between what combines and is combined, but one.

Zen Buddhism, also is not mere philosophy nor moral nor ethics, since it does not pursue any of Truth, Good, Beauty and Holy, but the human existence itself from which these values are brought out. The ultimate value must exist when man releases himself from these dualistic values and gets the freedom to give his creative value to the other. Zen Buddhism is not a religion so far.

Zen Buddhism which I concern here is out of this conception. I would interpret Zen Buddhism as an appearance of human longing to be eternally so that it may have opportunity to encounter with world religions, so far as we concern the encounter of religions as the encounter of man. And in this respect Zen Buddhism also can not be out of encounter of religions. As the matter of fact Zen Buddhism has been thought as one of representatives among world religions since Zen master Sōen Syaku attended the world periament of religions at Chicago 1893 as one of four representatives of Japanese Buddhist. For Zen Buddhism, it could be a dawn of what prof. W. C. Smith calls "personalization of comparative study of religions" or encounter with world religions. Nowadays Zen Buddhism is so popular

1) See the book "The History of Religions-Essays in Methodology" edited by Mircea Eliade and Joseph Kitagawa, the University of Chicago Press, 1959. 
in the world that it begins to degenerate into the secularism. Zen Buddhism, in this sense, stands on the crucial point today and those who perticipate it should not disregard this crisis.

\section{II}

Prof. Ernst Benz asserts that Zen Buddhism can be achieved only in the Buddhistic circumstance and through Buddhistic dsicipline and way of life which is the "ground" where Zen Buddhism stands on. He quotes Rudolf Otto's advice in his resent book "Zen in Westlicher Sicht" :

"Keine Mystik wolbt sich im Blauen, sondern jede steht uber einem Grunde, den sie selber nach Kräften leugnet und von dem sie dennoch immer erst ihr besonderes und mit anderswo gewachsenen Mystiken niemals identisches wesen erhält, und das gilt auch vom Zen."'(p. 32)

What he means here seems to be a criticism on so called "Zen snobism" in the western world. In his present book, he mentions that such snobism might be caused by Dr. Suzuki' fault by which he explained Satori Enlightenment psycologically as "the insight in the unconciousness" (eine Einsicht in das Unewußte) to make Zen Buddhism to be more familiar with western people and thus has Zen Buddhism secularized. Benz's criticism seems to me to be quite meaningful when we see the dialogue between Dr. C. G. Yung and Dr. S. Hisamatsu on "the Unconciousness and the No-mind in Zen". Because in the whole process of the talking, we do not see any point where two scholar's notions meet, and from this fact I understand that Zen Buddhism can not be interpreted by modern psycology no matter how Dr. Yung asserts that only modern psycology can be possible to understand Satori (die moderne Psychologie allein imstande sei, das Streben nach satori zu verstehen). Zen Buddhism, at any

2) "Zen in Westlicher Sicht: Zen-Buddhismus-Zen Snobismus", Ernst Benz, O. W. Barthvarlag, Weilheim/OBB, 1962.

3) “F. A. S." No. 39, issued by Association For Self-Awakenning, Kyoto, 1959, P. 10.

4) Benz's above mentioned book, P. 30 . 
mean, has to be a genuine religion which stands on its unique ground.

\section{III}

As Prof. W. C. Smith mentions, in some religion what was truth in the past can be untruth in the present, hence what can be spoken with authority is of its present situetion. There can not be any immutable truth in the religion since religion is the personal matter in man's life. And this is exactly what Zen Buddhism has asserted through its history. From such a essencial nature of religion, we can easily understand that "personalization" of comparative study of religion or the encounter of world religions is reasonably to be needed.

Prof. J. Kitagawa of Chicago University writes:" There are three essencial qualities underlying the discipline of the history of religions: First is a sympathetic understanding of religions other than one's own. Second is an attitude of self-criticism, or even skepticism, about one's own religious background. and third is the "scientific' temper......."

When we talk or write about Christianity, for example, we have to be sympathetic or polite. Because some of our audience or readers are Christian even when we use our own language. Accordingly what we talk or write has to be recognized by Christian. Otherwise it could not have any meaning even if it may be authoritative enough. In this respect, Dr. D. White of Macarester college has quite sympathetic understanding to Zen Buddhism when he itemizes it as follows;

1 a fresh because "forign" approach to human problems

2 a religious practice without any institutional dead weight

3 a religion without religiousness, religiousity

4 the use of doubt and despair to get beyond intellect, feelings

5 implementation of the whole person and all of life in religion

6 meditation with action

7 actual men and women who have attained enlightenment willing to teach

5) "The History of Religions" Chap. I.

6) Note for Pendle Hill seminer on "the Creative Encounter of World Religions" On Zen Buddhism, What Zen can contribute to the West. 
and help on the path

8 can be adopted without giving up one's Western religion

9 involves a philosophy which is compatible with Western thought: "nondualism" without " monism"; the actuality of egolessness; " a God beyond the God of theism"; the reality of wisdom;" compasion" as prime virture; a "naturalism" without materialism

As a student of the other religion, we have to be "impercial". The world "impercial", according to Prof. W. C. Smith, does not mean to be a secular rationalist who does not belong to any religion, but to be a keen seeker of particular religion and yet sincere student of the other religion. In this point, the past Zen student was too much either to be rational thinker or to be dogmatic. In fact; in Zen Buddhism, to be scholar and to be monk can not co-exist because of its paradoxical characteristic. Now we Zen students have to be awaken to be Bodhisattva whose final purpose of religious practice is not to attain Satori Enlightenment and be a Buddha, but to keep his vow eternally both to attain Satori and to. save the other. Here we will find the possiblity to be a member of the encounter of world religions.

Last of all, I will point out one of good example of the field where personal encounter of world religions is being practised. It is Pendle Hill, Wallingford, Pa, U. S. A which is Quaker center for. religious study and practice. Every year, it has approximately fifty residents who come from all over the world and represent various sects or denominations, and those people are given very warm experiences of encounter with different people through the communistic life. We have to make utmost effort to establish such a field of encounter everywhere in comming future.

- It is my great pleasure to announce that Zen Bunka Kenkyusho, the institute for Zen study and practice, has been established at Hanazono College, Ukyo-ku, Kyoto, Japan on November 20th, 1963. I hope this institute will accomplish its purpose in the presentation of it's place for the world people to encounter each other as it declares. 